\title{
The Coverage of "Spousal Homicide" in the Ethiopian Community in the Israeli Daily Press
}

\author{
Efrat Shoham ${ }^{1}$ \\ ${ }^{1}$ Department of Criminology, Ashkelon Academic College, Ashkelon, Israel \\ Correspondence: Efrat Shoham, Department of Criminology, Ashkelon Academic College, Ben Tzvi ${ }^{\text {st }} 12$ \\ Ashkelon, Israel. Tel: 972-8-678-9232. E-mail: shoham@netzer.org.il
}

Received: December 15, 2012 Accepted: January 30, 2013 Online Published: May 30, 2013

doi:10.5539/jpl.v6n2p185

URL: http://dx.doi.org/10.5539/jpl.v6n2p185

\begin{abstract}
In the recent years, Ethiopian immigrants in Israel have been making headlines mainly in connection to domestic violence and murder. For the last decade, 30 Ethiopian women were murdered by their husbands. Iyengar (1991) distinguishes between two types of framing in news coverage. An episodic frame, which focuses mostly on the specific details of the events, and a thematic frame, which deals with the broader context within the events occur. In the case of the thematic frame, the source of the problem is found in the wider social circles, or the care-giving facilities, and they bear the responsibility for solving the problem as well. According Carter and Weaver (2003) the media's presentation of violent stories constitutes means of social control, which encourages fear that leads to the search for authoritative and one-dimensional solutions. In order to examine the nature of the press coverage of Ethiopian husbands who murdered their wives, two of the most popular daily newspapers in Israel have been chosen. The sample includes all the articles regarding eight Ethiopian women murdered by their partners during the years 2007-2009. It seems as the press coverage of the murdered Ethiopian women makes use of both types of frames: episodic and thematic. Strengthening the image of the poor, criminal black immigrant plays a dual functional purpose, Illustrating, on the one hand, a clear line between the dangerous and the normal and, on the other hand, removing responsibility from the rest of the Israeli society.
\end{abstract}

Keywords: spousal homicide, press coverage, Ethiopian community, Israel

\section{Introduction}

The media coverage preserves a cultural framework that is comprised of various myths regarding spousal abuse. Meyers (1997) presents the viewing points of various feminist researchers view news reports as a result of male perceptions, which immortalize stereotypes and myths and reduce the intensity and the threat behind these behaviors. Carter (1998) claims that there is a general social denial regarding the extent of domestic violence. Violence is regarded as something "normal", but not acceptable. According to her, spousal abuse is perceived by the audience as an inevitable part of "normal" natural heterosexual relationships.

According to Lemish (2007), the media coverage on the topic of domestic violence plays the role of a double-edged sword. On one hand, the media's preoccupation with this topic puts it on the public agenda and makes it a main topic that needs to be addressed and dealt with, in addition to its consequences. This also caused substantial social changes in law enforcement, as well as other treatment agencies. On the other hand, the focus on the issue of violence towards women is a part of a trend where women are usually presented in the media as victims or related to victims, a trend that continues to determine the social inferiority of women who need protection and saving by the male patriarchal systems.

Daily occurrences of domestic violence aren't viewed by reporters as newsworthy. Cavaglion and Shoham (2012) demonstrate that at the base of reports regarding violence, and specifically sexual violence, are a number of directives of "common sense judgment" directives, regarding the normality that constructs the moral structure of these stories. The ways in which the ideological formations of "normality" are weaved into the public conversation regarding the "ideal" "traditional" family are especially important. Victims that were constructed in the media as those who crossed the boundaries of "normal", "appropriate" or "acceptable" will be held accountable for their victimhood (Koren \& Efrat, 2008). The process of distancing and de-familiarizing of women exposed to domestic violence is assisted by the basic concept that assumes that the world isn't random and bad things happen to bad people. 
Lundman (2003) suggests the following three main reasons to explain why newspapers are prone to cover murders. Local murder events project onto the world that surrounds us and allow law-enforcement agencies to draw out an image of the events according to the social and cultural perceptions. The ethnic and national identity of the killers, and mainly that of the victims, is a part of the information that the law enforcement systems pass onto the media. The media continues to follow-up on the story, and by doing so heightens its centrality and importance in the eyes of their viewers. These stories, being published in newspapers, are used as a base for further broadcasting by television and radio. These entities use the newspaper coverage as background material, which allows imaging the event from different angles.

In Lundman's opinion, news coverage of murders is the direct result of journalists estimating the newsworthy value of murder stories. This value reflects, to a great degree, gender and racial stereotypes. Carter and Weaver (2003), claim that the media's presentation of violent stories constitutes means of social control because it radicalizes the imbalance of power and encourages fear, which leads to the search for authoritative and one-dimensional solutions. The public discourse on the causes of deviant behavior does not only address a chronological string of events, but also their moral aspects (Cavaglion \& Shoham, 2012). For every cause and effect there is both an empirical dimension and a moral one.

Iyengar (1991) distinguishes between two types of framing in news coverage. An episodic frame, which focuses on capturing events such as describing the characterization of the killing husband, the victim, or describing the murdered woman's family by interviewing neighbors and care-giving facilities; and a thematic frame, which deals with the broader context within which the events occur. In the case of the thematic frame, the source of the problem is found in the wider social circles, or the care-giving facilities, and they also bear the responsibility for solving the problem as well.

Contrary to the media's dealing with parents who murder their children (Cavaglion, 2009), a subject that causes a great deal of confusion and severe discrepancies between social expectations and reality- the attitudes towards husbands who kill their wives, especially amongst peripheral groups, minorities and immigrants- is perceived as the natural continuation to social distress and a non-adaptive lifestyle among specific segments in the society. The following paper will address the different techniques applied by the written media for constructing the public image of Ethiopian husbands who murder their wives.

\subsection{Husbands Who Murder}

The research dealing with men who murdered their partners- often regarded as Intimate Partner Homicide, Spouse Killing or Uxoricide- developed mainly in the past three decades (Houel, Mercader \& Sobota, 2003). While most of the crimes against men are carried out by strangers - usually other men - women are hurt, raped, beat or murdered primarily by their intimate partners (Bachman \& Saltzman, 1995).

The most common type of murder within a family is the killing of a woman by her partner. In most Western societies, the number of women killed by their male partners is $2-5$ times higher than the number of men killed by their female partners (Elisha, 2007). Furthermore, it was found that violence against women in a dating relationship is as equally common as violence against married women (Browne, Williams \& Dutton, 1999).

Murders of intimate partners constitute $40 \%-50 \%$ of the total amount of murder cases involving women in the United States, whilst the murders of men by their female partners is estimated at only $6 \%$ of the murder cases involving men (Nicolaidis et al., 2003). Elisha (2007) explains that murder of a partner can occur at any age, by anyone from any stature, with any level of education and of any ethnic origin.

The most prominent motive for the killing of women is jealousy that stems from suspicion, or discovery of infidelity, and primarily the result of a woman's desire to separate from her partner (Shackelford, 2001). These crimes are often referred to, by the media and law enforcement agencies, as "crimes of passion", which occur as a woman intends to leave her partner or recently after leaving him (Serran \& Firestone, 2004).

\subsection{Who Are the Ethiopian Immigrants?}

Rabbi Shlomo Goren, the Ashkenazi Chief Rabbi of Israel, claimed that the members of the Ethiopian community were not descendants of any Israeli tribe, and that there was the concern of assimilation with the non-Jews over the generations. Unlike him, Rabbi Yosef, The Sfaradi Chief Rabbi of Israel, determined that the community of Ethiopian Jews is a genuine Jewish community, and therefore has to be brought to Israel as part of the Right of "Return law", despite the Ministry of Immigration's report that denied their Judaism and despite the opposing opinion of the Ashkenazi Rabbinate (Cavaglion \& Shoham, 2012).

In light of the Rabbinical controversy regarding the issue of Ethiopian immigrants` Judaism authenticity and their religious and ethnic status, the massive immigration from Ethiopia began in the early 1980's. Most of those 
who immigrated were housed in absorption centers, caravan sites or hotels, which led to a complete segregation of the newly-arrived Ethiopian immigrants from the rest of the population. The immigrants brought with them great cultural diversity, which increasingly led to a condescending and patronizing attitude on part of the establishment, as well as fear and racism on part of their surrounding population.

As they arrived to Israel, the Ethiopian Immigrants had to overcome the array of difficulties that come with cultural differences from the receiving population: searching for workplaces, finding educational institutions that are suited to the traditional character of the ethnic group, dealing with various elements within the establishment that question their Judaism, racism, questions of identity amongst the youth, as well as general atmosphere of xenophobia. The relocation to Israel collapsed the traditional social (patriarchal, rural) structures and altered the social understanding of the familial system within the Ethiopian ethnic group (Weil, 1998). What was considered in Ethiopia as "educational spanking", and as such was accepted as part of the social norm, was perceived in Israel as domestic violence.

The extended family was scattered geographically. Ethnic authority figures, the original priests, the Kayases and Shmeglutzes gradually lost their power. At the same time, women had been empowered and gained financial independence, and the men were neglected and lost their status, and mainly their dignity. While in Ethiopia the man was the head of the family and its most honored member, in Israel the men had trouble fitting into the work force, and lost a great deal of their patriarchal dignity as the family heads and providers (Edelshtien, 2011) .Kassan, Suffer and Keidar (2005) describe numerous factors that might increase the number of domestic violence incidents towards women amongst Ethiopian immigrants, and pointed out the following:

a. Gender role-reversal - women have gone from being passive followers to being providers, and have integrated into the various social circles which have left the men behind.

b. Weakening of the traditional social stature of patriarchal leadership - the institutions of leadership continued to be respected by certain parts of the community, though without formal recognition on behalf of the absorption and welfare offices. This reality created two parallel and synchronized systems, Whilst the women started to make use of the formal welfare opportunities made available by the state of Israel, the men continued to hold onto traditional institutions which emphasized the centrality of the family and the man's place in the family.

c. Professional preconceptions and malpractice by welfare and law-enforcement elements, which were not sensitive to the cultural differences between the immigrants and the receiving population, often unintentionally created, frustration and violence.

d. Social and financial adaptability issues, which might increase existing strain and violence between partners.

\subsection{The Media Coverage of Ethiopian Immigrants}

It appears as though ethnicity in Israeli society has been designated to groups that have been deemed as weak or as minorities, whilst the dominant group becomes a representative of "the society", or "the Israelis" (Herzog, 1985).

In the media, amongst the various groups that migrated to Israel there are varying degrees of preferential treatment, for a variety of reasons. The Ethiopian immigrants are granted a regard of pity by the media. There is a dichotomy in the way Ethiopians are covered and described. On the one hand, there has been coverage with regards to topics bearing a negative undertone. On the other hand, they have been protected by the press in some of the stories. Coverage of the Ethiopian immigrants raises images relating to the "other", like the existence of doubt in their Judaism, crime and violence. On the other hand, the media protects them by benevolently presenting these very immigrants as a positive minority that is vulnerable, weak and dependent, and yet has strong Zionistic emotions and esteem for family values.

However, Stanley Cohen (2001) claims that the very act of attempting to bring forth a positive image for the minority group leads, by itself, to stereotypical thinking against them. The unusual success story rather goes to strengthen the negative stereotype insofar as "the exception to the rule indicates the rule". A good illustration of this can be found in a television campaign launched by the Jewish agency in honor of the 30th year anniversary of the Jewish immigration from Ethiopia to Israel. The campaign's purpose was to try and change the negative image attributed to members of the community by presenting a label of success, and after a short moment appears over the label an Ethiopian who says, "didn't think it was me, did you?" This enraged members of the Ethiopian community, who claimed that the media campaign only strengthens and perpetuates the assumptions that the successful Ethiopian immigrant is only the exception, and ask why must they struggle for their place in the Israeli society. Newman (2006) explains that during the process of social construction of various social issues, 
the different social groups struggle over the meaning attributed to actions, groups and people. The more socially powerful a group is, the more likely it will be that their perceptions will become so popular and so obvious, that objecting them will appear counterintuitive and unreasonable.

Between 1984 and 1996, public health authorities in Israel maintained a secret policy of discarding blood donations made by Ethiopian-Israeli citizens and immigrants (Seeman, 1999). Officials later attempted to justify this policy on the grounds that immigrants from Ethiopia were subject to high rates of infectious diseases (especially HIV). In 1996, this led to an explosive and violent confrontation between Ethiopian-Israeli protestors and agents of the state, including the police and public health authorities. This essay explores the cultural and political context of that confrontation, including the discourse of political violence caused by it. The conflict between Ethiopian-Israelis and the state was located within a wider set of political contexts, including the Israeli-Palestinian conflict, which was linked to it through a shared trope of "spilled blood" common to both.

One of the most prominent examples of the Israeli media's ambivalent attitude towards the Ethiopian group can be found in an editorial published by the very famous editor of Ma'ariv newspaper Shmuel Schnitzer in August 19th, 1994. This crass article against the immigration of the Falash Mura to Israel was presented under the title "Import of Death". In this article Schnitzer protested against the immigration of Falash Mura, who among other things might carry dangerous and contagious diseases in their blood, to Israel. The Falash Mura (The Modern Converted - "Anusim") are allegedly Ethiopian Jews who were forced under duress into the Christian religion by their environment and who now wish to return to Judaism and immgrate to Israel. Some are returning to the practices of Judaism, living in Falash Mura communities and observing Jewish Commandments. Beta Israel's spiritual leaders argued for the acceptance of the Falash Mura as Jews. This claim has been a matter of controversy within the Israeli society.

The article titled "Import of Death". sparked a public outcry that peaked in March 1997, when Schnitzer was recommended for the Israel prize in the field of written journalism. The Journalism Committee concluded that Schnitzer's article incited racism, which constitutes a criminal offense. Furthermore, the committee added that Schnitzer's article:

includes unfounded allegations based on race and ethnicity [...] the wording of the article will naturally and inevitably lead to contempt and reservations against the Ethiopian people in particular and as a whole [...] in its publishing there is a clear and present danger, which will severely hurt the feelings of the Ethiopian people in Israel. The damage of these types of publications caused to the resilience of the Israeli society as an immigrant-absorbing society is serious and severe [...] (Seeman, 1999).

The depiction of Ethiopian immigrants by Israeli media as dangerous and as "others" was further strengthened during 1996 amidst what became known as "the Blood Affair". Upsurges about this issues rise again from time to time when hundreds of Ethiopian Jews and their supporters march in protest of what they claim is humiliating and racist treatment. In general, these marches still address an incident in which Ethiopian-donated blood had been thrown out, as a routine of Magen David Adom (The Israeli equivalent to the Red Cross) blood drive (ynet, June $\left.11^{\text {th }}, 2006\right)$.

In a study that examined the representation of Ethiopians in Israeli media (Bahar, 2003), it was argued that the vast majority of articles dealing with the Ethiopian community presented them with regards to poverty, racism, discrimination, diseases, drugs and murder. Ethiopians are not portrayed as being an integral part of the Israeli society. It is nearly impossible to find an instance when a person of Ethiopian origin appeared in a broadcasted discussion as a topical expert in a matter that is not ethnicity related.

Ever since the ruling of Rabbi Ovadia Yosef's (one of the most eminent Sefaradi Spiritual leaders in Israel until today) ruling in 1973, the echoes of the public debate regarding the Judaism of Ethiopian immigrants have not quieted. The immigrants continue to claim strong religious faith and observance of Jewish values, as they were kept in their lands. The Rabbinical establishment, on the other hand, rules that their distance from contemporary Judaism requires extra-caution when considering the daily customs of their Judaism. The issue of doubt in the immigrants' Judaism, the struggle for acknowledgement as Jews, as well as the infiltration of Christian elements into Israel through different waves of immigration, only strengthens in the public discourse the foreignness of the Ethiopian group and helps to strengthen the group's various ethnic stigmas.

\section{Method}

In the recent years, Ethiopian immigrants have been making headlines mainly in connection to domestic violence and murder. For the last two decades, 30 Ethiopian women were murdered by their husbands. In order to examine the nature of the press coverage of Ethiopian husbands who murdered their wives, two of the most 
popular daily newspapers in Israel have been chosen (Ma'ariv and Yediot Ahronot). The sample includes all the articles $(n=16)$ regarding eight Ethiopian women murdered by their partners during the years 2007-2009. The 16 articles were analyzed according to four criteria: The image of the Ethiopian couple, the type of the article (news reports, news articles, profile stories, editorial articles or personal interviews), the formative components (Location in the Newspaper, size, pictures), and main theme.

\section{Findings}

Several recurring themes appeared throughout the various articles:

- All of the reports stated that the origin of the offending male is Ethiopian.

- All of the reports included characteristics of the events that only included the factual outlook, but disregarded the circumstances. These reports were usually short, without pictures, and focused on the details of the murder itself.

- All of the reports included references to other Ethiopian women who were killed by their partners, as if constructing a phenomenon.

- In most of the reports, the women were described as "quiet, good women who were mostly unnoticed." Most of the killing husbands are also described as "quiet, almost unheard, or unfelt," or as being intoxicated or unemployed.

- In most of the articles, excluding one, there was not a single constructive or political message regarding combating the affliction which had raided the community, in the opinion of the journalists.

- When the articles regarding violence against Ethiopian women were online, the readers added talkbacks of their own, generally racist and offensive in nature. The publication of these talkbacks was made possible despite regulations requiring the users to maintain a "clean" and unbiased language. Amongst the talkbacks could be found comments such as: "The Ethiopians are ruining the nation!!" "Death to Blacks," "I'm telling you, no ethnic group is more brutal than them!" "The Ethiopians are a deadbeat people," and more.

All of the stories that dealt with the killing of the Ethiopian women appeared in News of the Day sections and not as position papers, headlines or editorials. The story was told once only, without follow-up or profile; in most of these articles there is a mention of the other Ethiopian women who were killed that year, and add details of previous acts of violence that led to their killings. The stories detail the way in which the women were murdered, for example: "she was covered in blood," "her whole chest was with stab wounds," "he stabbed her and only stopped when the knife broke." The articles list the number of the victims' children and their location during the event. The articles detail who found the body, how it was found and what was the condition of the husband, as well as what the neighbors say about the family. In four out of the seven cases, the couples were described as a "warm couple in reasonable financial status," "normal people who don't stand out," "I really can't believe it's them." The women are all described as mothers, quiet and unfelt. "She was as quiet as a mouse, a good woman," explained a neighbor. "The husband was a quiet type as well; you wouldn't hear a word out of him. They looked like the model family."

Despite the neighbors' descriptions, the titles cry out, "Who will stop the violence against women in the Ethiopian community?" (Ma'ariv, January $18^{\text {th }}, 2009$ ) or "The Ethiopian community: 11 murdered in 4 years" (Yediot Ahronot, December 23 $3^{\text {rd }}, 2008$ ), as well as bylines such as "Help them," "Social worker: The writing was engraved in the wall", "Murder amongst Ethiopians: and the establishment ignores it All", "Out of the 5 Ethiopian victims, mother of 9 killed" (Yediot Ahronot, June $\left.10^{\text {th }}, 2007\right)$.

\section{Discussion}

In general, one can state that the killing of the Ethiopian women does not constitute a preferred news story. Almost all the cases of domestic violence between Ethiopian couples, which do not end in murder, do not reach the papers' attention. The Ethiopian women do not constitute the "ideal victim" for a murdered woman (Jermyn, 2001), and the violence against these women is perceived as trivial and as part of the primitive and non-adaptive lifestyle the Ethiopians bring with them from their homeland. Tuchman (2009) explains that the news do not reflect the reality but rather construct it. News coverage of minority group members tends to ignore them or to grant them negative coverage. This tendency brings with it a focus on topics such as crime, social unrest, and socio-economic distress. This type of coverage implies that they are the "other", who threatens the social order. Their lives are perverse and their social and economic distress stems from difference and a primitivism from which they function (Laor et al., 2004).

In all of the articles that were surveyed it was mentioned that the victim was an Ethiopian woman, this in complete contrast to the Israeli news articles which do not mention the place of origin for murdered Israeli women. Lemish 
(2007) explains that referencing the origin of the woman helps the media in saying to the public, "yes, it is awful, but it won't happen to us." Linn (2003) claims that in order to tell a story that is complex, interesting and short, the journalist must rely on familiar social frames. This reliance allows the reader to quickly decipher old social information. In fact, the use of stereotypes is a type of shorthand writing style which allows the observers to assemble their own prototype of the event and those who took part in it.

\subsection{Transparent and Dangerous}

Emphasizing the Ethiopian origin of the assailant and victim, in coverage of domestic violence, aids in presenting members of this community as "others", as different and even as dangerous. These reports, which deal with the murder of women, almost do not discuss the circumstances from which these violent incidents stem amongst the Ethiopian people, but rather focus on the situational characteristics of a violent event. Portraying the murdering partners as drunk or deadbeat strengthens the negative image of the entire ethnic group, which is perceived by its surrounding neighbors as a homogeneous one. Nevertheless, portraying the couples as being "unfelt," "quiet" and "not standing out" juxtaposed with the chilling description of the murder itself, elevates even further more the level of danger attributed to the Ethiopian husbands. This description strengthens the fear from the entire ethnic group, since one could not possibly know "which one of them is more dangerous." They are quiet; they do not stand out, but are capable of horrific acts of murder. The feeling of danger is greatly accentuated when one can not associate a person with external behavioral characteristics, signs or symptoms, which would allow his environment to beware of him. It can be said that focusing on docile aspects of the killer and victim almost clandestinely, strengthens the sense that the only characteristic the environment can make use of in order to avoid dangerous situations is the murdering husbands' affiliation with the Ethiopian community, like a street sign saying, "Warning: Dark Skin Ahead." Using the words of Joel Best, speaking of random violence, we imagine a world in which the general population of potential victims shares the risk of being attacked by these likely attackers. Most of this violence also seems to be lacking a pattern, meaning that it can happen to anyone, that it is pointless - it happens for no clear reason at all, and it is becoming increasingly common (Best, 1999).

It seems as though in the cases before us, coverage of the murdered Ethiopian women makes use of both types of frames: episodic and thematic. On one hand, these articles describe in details the characteristics of the couple, the killer, the victim, the family, the children, their employment status and mental health, as well as detailed information about the murder itself. On the other hand, these articles emphasize the fact that the problem is of the entire ethnic group, which is unable to integrate socially and economically integrated, and this is why these things continue to happen.

As mentioned above, nearly all articles state that the parties involved in these violent acts are of Ethiopian origin. The broad media coverage of events such as the random killing of the young beautiful Israeli girl Ma'ayan Sapir on a Friday evening in a city at the center of Israel by a young Ethiopian man whom she happened to have met as she crossed through a garden in city center; or the killing of the Ethiopian wives in the absorption center in the south and the north of Israel, remind everyone of the killers` and victims' ethnic affiliation. The perpetual reference to the killers' and victims' ethnic origin aids the media in deciding "who is dangerous and who is not" within the Israeli society, who has accepted social norms and conventions and who has cast themselves outside those norms, and therefore it is clear that these types of events will occur around these very types of people. It seems that despite the professional ethics code of written journalism, which formally seeks to minimize this process of estrangement, when dealing with news articles regarding acts of violence in the Ethiopian community, this code is almost never applied. Despite the fact that the phenomenon of violence in general, and the murder of women in particular, is an affliction which affects all parts of Israeli society, most reports of the murder of women state the fact that the family - an Ethiopian family, blessed with many children - lived in a weak and neglected neighborhood, and by doing so sharpens the impression that all members of the Ethiopian community are of poor, underprivileged families who's many children are neglected.

The manner of topic presentation in the media makes the reader believe that the murder of women by their partners is primarily a characteristic of the Ethiopian community. The press also points, in some of the reports, a blaming finger against the entire community, including their leaders, who are portrayed as weak and passive and as not doing enough in order to uproot this problem from within the community.

\section{Conclusion}

The frequency of the story's appearance in the press, the visual means to support it, its titles, the position in the body of the paper - all assist in constructing a certain perspective of the problem and the social reality from which it works and which it reflects. 
It can be said that adding information which explains that the killer is Ethiopian, is not made to increase the understanding of the event, and its addition only strengthens the digressions of the dangerous margins of society. Strengthening the image of the poor, criminal black immigrant plays a dual functional purpose, illustrating, on the one hand, a clear line between the dangerous and the normal on one hand and, on the other hand, removing responsibility from the rest of the Israeli society. As was stated by the Israeli Minister of Interior, Mister Eli Yishai in 2010, "Absorption of foreign and dangerous non-Jews, infiltrators and other asylum seekers is what will bring havoc on us all." It seems that the dark skin color of Ethiopian immigrants and the question of doubt in their Judaism allow binding them together with other dark-skinned groups of legal and illegal foreign workers - The foreign workers who are perceived as a threat to the existence and stability of the Israeli society and further strengthen the association of negative traits to these immigrants. It seems that even with hundreds of hours of commercials it will be difficult to erase the deterring image of the "violent and dangerous black" from the mind of the neighbor, the schoolmate, and employer or decision maker.

\section{References}

Bachman, R., \& Saltzman, L. E. (1995). Violence against Women: Estimates from the Redesigned Survey. Washington D.C.: Department of Justice.

Bahar, A. (2003). The Status of the Ethiopian Community in the Media - An Overview of the Coverage in Israeli Press. Jerusalem: Israeli Association for Ethiopian Jews.

Best, J. (1999). Random Violence: How We Talk about New Crimes and New Victims. Berkley: University of California Press.

Browne, A., Williams, K., \& Dutton, D. (1999). Homicide between intimate partners. In M. D. Smith, \& M. A. Zahn (Eds.), Studying and preventing homicide. London: Sage.

Carter, C. (1998). When the "Extraordinary" Becomes "Ordinary": Everyday News of Sexual Violence. In C. Carter, G. Branston, \& S. Allen (Eds.), News, Gender and Power (pp. 219-232). London: Rutledge.

Carter, C., \& Weaver, C. (2003). Violence and the Media. Buckingham: Open University Press.

Cavaglion, G. (2009). Mad or Bad? Fathers who Kill and Press Coverage in Israel. Child Abuse Review, 18, 127-143. http://dx.doi.org/10.1002/car.1028

Cavaglion, G., \& Shoham, E. (2012). Cult, Violence and Sex, Social construction of deviance in post modern Israel. New York: Nova Science Publishers.

Cohen, S. (2001). States of Denial: Knowing about Atrocities and Suffering. Cambridge: Polity Press.

Edelshtien, A. (2011). Intimate homicide in Israel. Be'er Sheva: Ben Gurion University Press.

Elisha, E. (2007). Intimate homicide: The typology of husbands who murdered their wives. A window to the prison, 11, 27-40 (Hebrew).

Herzog, H. (1985). Social Construction of Reality in Ethnic Terms: The Case of Political Ethnicity in Israel. International Review of Modern Sociology, 15, 45-61.

Houel, A., Mercader, P., \& Sobota, H. (2003). Crime Passionnel, Crime Ordinaire. Paris: Presses Universitaire (French).

Iyengar, S. (1991). Is Anyone Responsible? How Television Frames Political Issues. Chicago: University of Chicago Press. http://dx.doi.org/10.7208/chicago/9780226388533.001.0001

Kassan, L., Suffer, G., \& Keidar, L. (2005). Domestic Violence among Ethiopian Families in Israel. In M. Shabtay, \& L. Kassan (Eds), Molo- Alem: Women and Girls from Ethiopia (pp. 111-136). Tel Aviv: Lashon Zaka (Hebrew).

Koren, A., \& Efrat, S. (2004). The Coverage of Rape in the Israeli Popular Press. Violence against Women, 10, 1056-1074. http://dx.doi.org/10.1177/1077801204267378

Laor, N., Alpert-Lefler, N., Avraham, E., \& First, A. (2004). The absentees and the presence during Television prime time. Report to the Second Broadcasting \& Television Authority in Israel, Jerusalem.

Lemish, D. (2007). The Politics of Minority Exclusion in the Media: The Image of Women Victims of Violence. In D. Caspi (Ed.), Media and Politics in Israel (pp. 185-207). Jerusalem/Tel Aviv: Van Leer Institute and Hakibbutz Hameuchad (Hebrew).

Linn, T. (2003). Media Methods That Lead to Stereotypes. In P. Lester, \& S. Ross (Eds.), Images That Injure; Pictorial Stereotypes in the Media (pp. 23-29). Westport, Connecticut: Greenwood Press. 
Lundman, R. J. (2003). The newsworthiness and selection bias in news about murder: Comparative and relative effects of novelty and race and gender typifications on newspaper coverage of homicide. Sociological Forum, 18, 357-386. http://dx.doi.org/10.1023/A:1025713518156

Maariv. (2009, January 18). (Daily newspaper). Retrieved from http://www.nrg.co.il/online/54/ART1/841/714.html

Meyers, M. (1997). News coverage of violence against women: Engendering blame. Thousand Oaks, CA: Sage.

Newman, D. (2006). Sociology: Exploring the Architecture of Everyday Life. Thousand Oaks, CA: Pine Forge Press.

Nicolaidis, C., Curry, M., Ullrich, Y., Sharps, Ph., McFarlane, J., Campbell, D., ... Campbell, J. (2003). Could We Have Known? A Qualitative Analysis of Data from Women who Survived an Attempted Homicide by an Intimate Partner. Journal of General Internal Medicine, 18, 788-794. http://dx.doi.org/10.1046/j.1525-1497.2003.21202.x

Seeman, D. (1999). One People, One Blood: Public Health, Political Violence and HIV in an Ethiopian/Israeli Setting. Culture, Medicine and Psychiatry, 2, 159-195. http://dx.doi.org/10.1023/A:1005439308374

Serran, G., \& Firestone, P. (2004). Intimate partner homicide: A review of the male proprietariness and the self-defense theories. Aggression and Violent Behavior, 9(1), 1-15. http://dx.doi.org/10.1016/S1359-1789(02)00107-6

Shackelford, T. K. (2001). Cohabitation, Marriage, and Murder: Woman-Killing by Male Romantic Partners. Aggressive Behavior, 27, 284-291. http://dx.doi.org/10.1002/ab.1011

Tuchman, G. (2009). Making News: A Study in the Construction of Reality. New York: Free Press.

Weil, S. J. (1998). The religious beliefs and practices of Ethiopia Jews in Israel (2nd ed.). Jerusalem: NCJW Research Institute for Innovation in Education (Hebrew).

Yedioth Ahronoth. (2007, October 6). (Daily newspaper). Retrieved from http://www.ynet.co.il/articles/0,7340,L-3456678,00.html

Yedioth Ahronoth. (2008, December 23). (Daily newspaper). Retrieved from http://www.ynet.co.il/articles/0,7340,L-3642725,00.html

Ynet. (2006, June 11). Ethiopian-donated blood had been thrown out. Retrieved from http://www.ynetnews.com/articles/0,7340,L-3322247,00.html

\section{Copyrights}

Copyright for this article is retained by the author(s), with first publication rights granted to the journal.

This is an open-access article distributed under the terms and conditions of the Creative Commons Attribution license (http://creativecommons.org/licenses/by/3.0/). 